\title{
13
}

\section{SELF-DETERMINATION WITH RESPECT TO LANGUAGE RIGHTS}

\author{
Jane Simpson
}

\section{Introduction}

In 1788 the whole of Australia was covered with people speaking one or more of at least 300 languages. In well-watered areas there were many languages; elsewhere one language (with different dialects) was spoken across more than a quarter of the continent. People were often multilingual, speaking the language of their community and those of neighbouring communities. There was no need for a common language across Australia, because people in each area spoke the language of their neighbours and perhaps those of their neighbours' neighbours. If they moved to another area, they generally expected to learn the language of the other area.

At the start of colonisation, the British colonists often made use of interpreters, but warfare, dispossession and new diseases resulted in an immediate and rapid decline in the number of people speaking the languages of the regions around the colonies. Once the British had become well established in an area, they imposed English as the language of government and as the language in which to access services (e.g. shops, paid work, medical help, justice and schooling). They saw no need to learn or recognise the languages of Aboriginal and Torres Strait Islander peoples, 
who then had to learn some English. A few missionaries encouraged literacy in Aboriginal languages and promoted mother-tongue medium instruction ('bilingual education') in schools.

In 1972, when Australia's policy of self-determination for Indigenous people was proposed, nearly 200 years of colonisation had resulted in many Aboriginal and Torres Strait Islander groups with different aspirations, and whose opinions were rarely considered. The policymakers were not Indigenous, and were trying to implement a policy of selfdetermination at a time when everyone was struggling to understand what self-determination actually meant.

Internationally, the right to self-determination had been adopted a few years earlier by the United Nations General Assembly in 1966. It was Article 1.1 of two covenants: the International Covenant on Civil and Political Rights (ICCPR) and the International Covenant on Economic, Social and Cultural Rights (ICESCR):

All peoples have the right of self-determination. By virtue of that right they freely determine their political status and freely pursue their economic, social and cultural development. ${ }^{1}$

ICCPR included rights related to language, the right not to be discriminated against on the basis of language (Articles 2.2, 24, 26), the right when charged to be given information in a language one can understand, and the right to an interpreter (Article 14.3a, f). But most significant was Article 27:

In those States in which ethnic, religious or linguistic minorities exist, persons belonging to such minorities shall not be denied the right, in community with the other members of their group, to enjoy their own culture, to profess and practise their own religion, or to use their own language. ${ }^{2}$

The ICESCR became part of Australian law in 1976, but it was not until 1986 that the ICCPR, with its stronger emphasis on language rights as individual liberties, became part of Australia's law.

1 UN General Assembly, International Covenant on Civil and Political Rights; UN General Assembly, International Covenant on Economic, 3.

2 UN General Assembly, International Covenant on Civil and Political Rights, 3. 
One thing missing in 1972 was the recognition that language rights are essential for effective self-determination. As primarily monolingual speakers of English, the policymakers had difficulty in imagining the needs and wants of people who did not speak English, and found it hard to realise that language rights, which they took for granted, might not be shared by others. For example, as Australian English speakers, they took it for granted that they could use English to talk with government officials, and that their children would be educated through their mother-tongue, English. These rights were not enjoyed by speakers of Indigenous languages in remote communities in 1972.

As language is both an individual and a social phenomenon, language rights are complex, bringing in both the rights of individuals and the rights of groups. Language is used both to communicate ideas (communicative rights) and to express associations (identity rights). The identity right to speak one's mother-tongue language or heritage language is guaranteed by ICCPR Article 27. Communication rights include the right to access information in a language one understands. ICCPR Article 14 guarantees this only for court proceedings, not for other important information such as health, education and government services. People cannot make the most of self-determination if they do not have access to the best information to make the best decisions for themselves and their family, because it is only presented in a language they do not understand. This was certainly the case in 1972 for many Indigenous people in remote communities.

Apart from the right to an interpreter, the language rights mentioned in ICCPR were basically individual liberties; they did not guarantee positive support for languages. For example, they do not mention the communication right for children to receive an education in a language they understand, as well as being taught effectively the language of wider communication. In the Australian context this was known as 'bilingual education'. When self-determination became policy in 1973, 'bilingual education' was given new legitimacy by the Whitlam Government. I will discuss the gradual acceptance and implementation of these rights from the start of the self-determination policy, focusing mostly on the literature and reflections of people involved in Indigenous education in the Northern Territory ${ }^{3}$ and, to a lesser extent, South Australia. ${ }^{4}$

3 Black and Breen, 'The School of Australian Linguistics'; Devlin, Disbray and Devlin, History of Bilingual; Hoogenraad, 'Critical Reflection'; Huijser et al., Finding Common Ground.

4 Simpson, Amery and Gale, 'I Could Have Saved You'. 


\section{Twentieth century}

A step towards recognising identity and communication rights came with the establishment of the Presbyterian mission at Ernabella in 1937. It had a strong policy of using the local language in preference to English, ${ }^{5}$ as part of a general policy of 'no compulsion or imposition of our way of life', which could be seen as an earlier recognition of the right to self-determination. ${ }^{6}$

In 1950, missionary organisation the Summer Institute of Linguistics (SIL) began work in Australia. Teams of SIL linguists worked with Indigenous people in remote Australia on Bible translation and language documentation. The linguistic and cultural insights gained in this translation work gave both Indigenous and non-Indigenous people better understanding of each other's languages and societies. Some other missionaries performed similar roles in the 1950s and 1960s: Beulah Lowe (Methodist Overseas Missions, Milingimbi) documented Yolyu varieties and helped communication between Yolyu and non-Aboriginal people, and Judith Stokes (Church Missionary Society, Groote Eylandt) learned Anindilyakwa and taught some Anindilyakwa people to read and write in their own language. But, as Rademaker shows, the attitudes of missionaries towards Indigenous languages and towards communicative rights was nuanced, in part because of the tension between assimilation, self-determination, and the uncertainty of the place of missionaries if they were not needed as brokers between Indigenous people, the wider Australian populace and the state. ${ }^{7}$

For non-Indigenous people, cross-cultural understanding received a boost when, in 1966, Presbyterian missionaries collaborated with the University of Adelaide to teach Pitjantjatjara as a university course. ${ }^{8}$ Another major step was taken in 1969 when the Uniting Church established the Institute for Aboriginal Development (IAD) in Alice Springs and then, in 1971, transferred it to an Aboriginal-controlled board of management. ${ }^{9}$ Its aim was to 'assist community development for Aboriginal people and provide cross-cultural education between Aboriginal and non-Aboriginal society'. ${ }^{10}$

5 Trudinger, 'Converting Salvation'.

6 Pybus, 'We Grew Up This Place', 10.

7 Rademaker, Found in Translation.

8 Simpson, Amery and Gale, 'I Could Have Saved You'.

9 Zoellner, Vocational Education, 77.

10 Institute for Aboriginal Development (Aboriginal Corporation) website, 2018, iad.edu.au/. 
These two-way exchanges through community development and attempts to learn Aboriginal and Torres Strait Islander languages were essential for Indigenous people gaining information that they needed in order to make the choices that the later policy of self-determination required.

The communication right of children to be educated in a language they understood also gained some traction when, in 1950, the Commonwealth Office of Education adopted a policy recognising that in some circumstances Indigenous languages should be used in education:

The language of instruction in Native schools shall be English, except where local conditions (e.g., where natives are still in a tribal or semi-tribal state) render bilingual instruction desirable. ${ }^{11}$

In practice, while education for Indigenous children in remote communities was greatly expanded, an assimilation drive promoted English above Indigenous languages. ${ }^{12}$ Rademaker discusses the implementation of this among Anindilyakwa children at a mission school on Groote Eylandt. ${ }^{13}$

Mother-tongue medium instruction was put forward as an ideal in 1964 with the Watts-Gallacher report on curriculum and teaching methods used in Aboriginal schools in the Northern Territory. ${ }^{14}$ Watts and Gallacher saw the importance of reducing the cultural divide between home and school. But they deemed bilingual education impractical at the time, given the lack of teachers who could speak Indigenous languages, among other factors. Other consequences of the Watts-Gallacher report included the establishment in 1967 of Kormilda College, a post-primary boarding school in Darwin for Indigenous children from remote areas. Once schooling for Indigenous children expanded, the importance of Indigenous teaching assistants as interpreters and classroom support was soon recognised, and so Kormilda College also ran short courses for Indigenous teaching assistants. This teacher training grew into an Indigenous tertiary institute, which was moved to Batchelor, Northern Territory, renamed Batchelor College, and established as a teacher training college in $1975 .{ }^{15}$ It is now called Batchelor Institute of Indigenous Tertiary Education (BIITE).

11 Quoted in Brian Devlin, 'Government Support for NT Bilingual Education after 1950: A Longer Timeline', 12, FOBL: Friends of Bilingual Learning, last revised 7 March 2019, accessed 2 June 2019, www.fobl.net.au/index.php/au-TI/history/71-government-support-for-nt-bilingual-education-after1950-a-longer-timeline.

12 Devlin, 'A Glimmer of Possibility'; Sommerlad, Kormilda.

13 Rademaker, Found in Translation, 70-84.

14 Watts and Gallacher, Report on an Investigation.

15 Reaburn, Bat and Kilgariff, 'Looking for a New Common Ground'. 


\section{Self-determination policy}

Access to information for Indigenous people was greatly expanded following the election in 1972 of the Labor Government, the adoption of the policy of self-determination and the great expansion of educational opportunities for Aboriginal and Torres Strait Islander people.

In 1972 at Nhulunbuy, Northern Territory, Dhupuma College was established as a bicultural/bilingual high school, with Gumatj as a school language. The seeds of 'both-ways' or 'two-way' education were sown. ${ }^{16}$ Many Indigenous people gained access to better English literacy, spoken Standard Australian English (SAE), numeracy and an increased understanding of non-Indigenous society through education at Indigenous high schools like Dhupuma, and through BIITE. ${ }^{17}$ However, the great gulf between the residential colleges and the home communities caused severe stress for many Indigenous students who felt they belonged nowhere. ${ }^{18}$

With the election of a Labor Government on 2 December 1972 there was a major push for mother-tongue medium instruction, spearheaded by the minister for education, Kim Beazley Senior, and the new Prime Minister, Gough Whitlam. ${ }^{19}$ The first five pilot programs began in 1973. While the initial programs were imposed from above, some programs were later established at community request. ${ }^{20}$ The bilingual educational approaches were informed by two reports, the Watts-McGrath-Tandy report by educators, ${ }^{21}$ and the O'Grady-Hale report by linguists. ${ }^{22}$ Both reports recognised the importance of Indigenous teachers. The O'GradyHale report also highlighted local control by Indigenous communities of education as a goal of bilingual education. ${ }^{23}$

The bilingual programs were not limited to traditional languages. Educators and missionary linguists also spearheaded a movement for bilingual education using Kriol (a new contact language that had developed

16 White, 'Finding the Common Ground'.

17 Huijser et al., Finding Common Ground.

18 Sommerlad, Kormilda.

19 Hoogenraad, 'Critical Reflections'.

20 Vaarzon-Morel and Wafer, "Bilingual Time"'.

21 Watts, McGrath and Tandy, Recommendations.

22 O'Grady and Hale, 'Recommendations Concerning'.

23 O'Grady and Hale, 'Recommendations Concerning', 2. 
in the Katherine and Roper River area). They recognised the importance of using in classrooms a language that children felt comfortable with, ${ }^{24}$ regardless of whether it was a traditional Indigenous language or a new language. The O'Grady-Hale report endorsed this view, which departed from the widespread view that contact languages like Kriol were to be discouraged as broken, inferior English. ${ }^{25}$

The new bilingual programs faced many obstacles: lack of models, lack of trained teachers, lack of materials (all foreshadowed in the reports), as well as opposition from senior education department officials. But the school workers were enthusiastic. ${ }^{26}$ Highlights of the bilingual education programs were the collaborations between Indigenous and non-Indigenous people in team teaching and in producing stories and materials in Indigenous languages through Literature Production centres. The team teaching approach was strongly supported by Beth Graham, an experienced teacher in Aboriginal schools who became an adviser in bilingual education in the Northern Territory Education Department in 1979. As she said, 'if children are to learn effectively, teachers have to teach together, plan together and learn together'. ${ }^{27}$ Team teaching produced much greater understanding between Indigenous and non-Indigenous people, and affirmed the role of Indigenous teachers in the classroom.

The need for more Indigenous teachers led the federal government to establish a Remote Area Teacher Education (RATE) program in 1976 through Batchelor College, as well as the School of Australian Linguistics (SAL) in Batchelor, Northern Territory (later the Centre for Australian Languages and Linguistics and part of BIITE). ${ }^{28}$ Both SAL and RATE students acquired skills in language documentation, literature production and translation expertise. An example is one of the first linguistics papers co-authored by an Indigenous person, the Ngalkbun and Kriol linguist David Nangan:golod Jentian, and a non-Indigenous linguist, John Sandefur:

David Jentian began the compilation of the wordlist and gave invaluable help in the analysis because of his knowledge of elementary linguistics gained while at the Aboriginal teacher Trainees course in Darwin. ${ }^{29}$

\footnotetext{
24 Meehan, 'Starting Out at Bamyili'; Sandefur, Kriol of North Australia.

25 Rademaker, Found in Translation, 54, 59.

26 Gale, 'Lessons Learned'; Gale, 'Boom and Then Bust'.

27 Graham, 'Reflecting on Team', 31.

28 Black and Breen, 'The School of Australian Linguistics'.

29 Sandefur and Jentian, 'A Tentative Description', 57.
} 
Meanwhile, in Western Australia, from 1975, around 600 people living at Strelley speaking mostly Nyangumarda and Manjiljarra began moves towards having their own independent school, the Strelley Community School. They wanted an Aboriginal-controlled school, a bilingual curriculum that was not purely for transition to English, a focus on adults as well as children and a curriculum that reflected their priorities. Liberman has described the community's belief that this type of school would 'guarantee Aboriginal self-determination in the future'. He quotes an elder: 'When the whitefellas come to this country, he bin kill 'em blackfella. Now we learn all this literacy, we win the country back'. ${ }^{30}$

Communication between many Indigenous people and governments was still poor. In 1979 the Aboriginal linguist and anthropologist Gloria Brennan published a research report for the Department of Aboriginal Affairs pointing out the need for interpreters for Indigenous people, especially in the Northern Territory. ${ }^{31}$ In Alice Springs, IAD began training Indigenous people as interpreters and as language teachers, teaching Indigenous languages such as Warlpiri and Arrernte, often to people who were working in Indigenous communities. Then, when mother-tongue medium instruction programs started, school staff sometimes organised language learning programs, which were seen as exciting and empowering. ${ }^{32}$ IAD staff also worked on major resources for communication, learners' guides, handbooks and dictionaries of Central Australian languages. ${ }^{33}$ Although IAD trained interpreters and provided free interpreting services, they had difficulty persuading courts and hospitals to make much use of them. ${ }^{34}$

Self-determination policy, with respect to language, addressed both identity rights and communication rights. Assertion of identity rights received bipartisan support in 1972 when the then Prime Minister William McMahon said on Australia Day that Aboriginal people 'should be encouraged and assisted to preserve their own culture, languages, traditions and arts so that these can become living elements in the diverse culture of the Australian society'. ${ }^{35}$

30 Liberman, 'Aboriginal Education', 141.

31 Brennan, The Need for Interpreting.

32 Ross and Baarda, 'Starting Out at Yuendumu'.

33 Simpson, Amery and Gale, 'I Could Have Saved You'.

34 John Henderson pers. comm. to J. Simpson.

35 McMahon, Australian Aborigines, 1. 
Respect for identity rights also grew concomitantly with respect for communication rights. The first person to make a speech in an Indigenous language in parliament was Neil Bell who had learned Pitjantjatjara as a schoolteacher working at Areyonga School. In 1981, as Labor member for MacDonnell, he made his maiden speech in Pitjantjatjara in the Northern Territory Legislative Assembly. It was a statement of respect for his constituents, and an important symbolic use of an Indigenous language in a parliament. For the first time also, the government began to have access to information about Aboriginal and Torres Strait Islander languages, with the introduction of a question on language into the 1976 Census.

The self-determination policy of the 1970s both supported and was supported by the assertion of communication rights, both in the education sector and in the interpreting domain. The new access to secondary school education and tertiary training, the bringing together of Indigenous people from across the Northern Territory for classes at Batchelor, and the training and placement of Indigenous teachers in schools, created a new generation who could share ideas and understandings about the changes that the self-determination policy could make possible. The new bilingual education programs provided a springboard for demands for more local Indigenous control of education.

\section{Beginning of reversal of self-determination}

In 1978 the Northern Territory was granted self-government, and the Northern Territory Government pushed back against the mother-tongue medium instruction model. Without warning, in 1980 the government closed down Dhupuma College in the midst of the school year. ${ }^{36}$ This was deeply shocking to the students, to their communities and to other schools across the Northern Territory. Bilingual education programs continued after self-government in the Territory, but always under threat. ${ }^{37}$

However, the 1980s provided much greater access to tertiary education for Indigenous people, access for non-Indigenous people to learn Indigenous languages and increased job opportunities for Indigenous people particularly in the school sector. A major achievement was the

36 Amagula and McCarthy, 'Red Ochre Women'.

37 Hoogenraad, 'Critical Reflections'; Nicholls, 'Death by a Thousand Cuts'. 
expansion and establishment of remote area teacher training schemes, so that Indigenous people living in remote communities could study at least part of the time based in their home community. By 1985 the number of campus-based students $(80+)$ at Batchelor College was close to the number of RATE students (75)..$^{38}$ These included Indigenous people from bilingual schools as well as from English-medium instruction schools. South Australia began the Anangu Teacher Education Program (AnTEP) in 1984, ${ }^{39}$ which provided similar training and opportunities for Aboriginal Education Workers in the APY (Anangu Pitjantjatjara Yankunytjara) Lands. At this time, the APY Lands schools, under South Australian education policy, were still bilingual.

Many Indigenous people saw higher education as a chance for taking control of their lives and communities:

Through RATE, we Yolngu see our chance of getting loose and getting rid of the harness and the bridle that the Balanda has long used to steer us in the direction that they wanted us to go and that is the way of Balanda. Through this type of teacher training we have a chance of getting educational skills so that we can work in our communities and put our qualification and what we've learnt into use in our own Homeland communities. We Yolngu would like to gather enough understanding and knowledge about Balanda law and system so as to understand and live with both laws and worlds. ... This will also make communications better between Yolngu and Balanda. ${ }^{40}$

The new cohort of Indigenous educators looked beyond presence in the classroom for presence in the curriculum. They proposed a 'both-ways' or 'two-ways' curriculum, to incorporate Indigenous perspectives in school education. ${ }^{41}$ It was most famously described by the late Dr Marika in her Wentworth Lecture when she talked about the 'both-ways' maths curriculum that staff at Yolyu schools had developed:

Ganma is a still lagoon. The water circulates silently underneath, and there are lines of foam circulating across the surface. The swelling and retreating of the tides and the wet season floods can be seen in the two bodies of the water. Water is often taken to

38 Reaburn, Bat and Kilgariff, 'Looking for a New Common Ground'.

39 Underwood, Response to: Achieving Equitable.

40 Ngurruwutthun, cited in Marika-Mununggiritj et al., 'The History', 43-44.

41 Keeffe, From the Centre to the City; Reaburn, Bat and Kilgariff, 'Looking for a New Common Ground'; White, 'Finding the Common Ground'. 
represent knowledge in Yolyu philosophy. What we see happening in the school is a process of knowledge production where we have two different cultures, Balanda and Yolyu, working together. Both cultures need to be presented in a way where each one is preserved and respected. This theory is Yirritja. ${ }^{42}$

There was a continued push for greater Aboriginal control of schools and, in 1983, Yipirinya School, an independent school in Alice Springs, finally achieved registration. Arrernte language was a medium of instruction.

The desire for Aboriginal control extended beyond running schools to other related matters. In 1982 David Wilkins, a linguist working for the Yipirinya School Council, prepared a draft research policy for Central Australia. Its first article was:

1.1 a) All research in Central Australia involving Aboriginal people must be approved, controlled and monitored by a body representing, and chosen by, the Aboriginal community, or communities, in which the research will take place. ${ }^{43}$

Wilkins's call for responsible linguistics was echoed in other work, as linguists and communities began to understand the devastating effect of English on the Indigenous language ecologies of Australia. Keeping Language Strong: Report of the Pilot Study for the Kimberley Language Resource Centre appeared in 1984 and made the case for establishing Indigenous-run language centres to help Indigenous people maintain their languages. ${ }^{44}$

Nationally, an important step forward in identity rights and for preservation of languages came with the first national policy on languages 'to recognize, value and take action to enhance the survival of Aboriginal languages and promote an appreciation and an awareness of them among non-Aborigines. ${ }^{45}$

From 1987 onwards, the Commonwealth Government began providing funds for Indigenous language maintenance and revival, through a grants scheme operated by the National Aboriginal Languages Program. Language centres were set up, along with many out-of-school initiatives, since school education is a state responsibility.

42 Marika, 'The 1998 Wentworth Lecture', 7.

43 Wilkins, 'Linguistic Research', 189.

44 Hudson and McConvell, Keeping Language Strong.

45 Lo Bianco, National Policy, 7. 
In terms of communication rights, reflections by Indigenous people involved in the schools of the 1970s and 1980s reveal the benefits that they saw in the new approaches to schooling, and the hopes they held for the future, ${ }^{46}$ although there was continued suspicion of formal schooling, especially when it seemed to be controlled by non-Indigenous people. ${ }^{47}$

Generally, understanding and communication was strengthened among Indigenous people and non-Indigenous people working with Indigenous people. Indigenous politicians, such as Bess Price and Alison Anderson, trained at Batchelor College and/or SAL, as did Indigenous leaders such as the late Jeannie Nungarrayi Egan, Mandawuy Yunupingu, John Joshua, Norma Nangali Joshua, Alice Limbiari Nangala/Napurrula Nelson, Michael Jampin Jones, Valda Napurrula Shannon and Geoffrey Jupurrula Shannon. Inspired by working in Indigenous schools, several nonIndigenous teachers became politicians, such as Neil Bell, Trish Crossin, Peter Toyne and Warren Snowdon.

When non-Indigenous authorities were mindful of the principle of selfdetermination, Indigenous people were consulted more often about their wishes. But it was often hard for people who did not speak English well to make truly informed decisions when there was little information accessible in their own languages. Complex concepts conveyed by the English words 'right', 'freedom' and 'non-discrimination' do not have one word equivalents in most Indigenous Australian languages. Holcombe describes the difficulties and length of time it took to unpack such concepts when translating the Universal Declaration of Human Rights into PintupiLuritja. ${ }^{48}$ That project took two years and involved two Pintupi-Luritja speakers, Lance Macdonald, an experienced interpreter, and Sheila Joyce Dixon, a Papunya local authority member; an anthropologist, Sarah Holcombe; and a missionary linguist, Ken Hansen, who had worked out of Papunya since 1966. It was published in 2015, more than 40 years after the self-determination policy was launched. ${ }^{49}$ The fact that in 2015 these ideas were still so hard to convey in an Indigenous language shows how far short Australia has fallen in protecting the communicative right of access to information in an understandable form.

46 Devlin, 'A Glimmer of Possibility'; Huijser et al., Finding Common Ground.

47 Keeffe, From the Centre; Liberman, 'Aboriginal Education'.

48 Holcombe, Remote Freedoms.

49 Macdonald et al., Universal Declaration of Human Rights: Pintupi-Luritja. 


\section{Increasing awareness of Indigenous languages}

Throughout the 1990s the identity rights of Indigenous people were strengthened. The National Aboriginal Languages Program funded more language centres and language revival programs. Renaming or restoring Indigenous placenames began. ${ }^{50}$ The ritual of 'welcome to country' increased, ${ }^{51}$ and began to contain words or sentences in the relevant local Indigenous languages. Using Indigenous languages in parliament has continued: in 2016, for the first time, a prime minister, Malcolm Turnbull, spoke in parliament in Ngunnawal. ${ }^{52}$

The communicative right to receive information in a language one understands was gradually strengthened, but with opposition. While a fulltime free interpreter service was available for immigrant languages, only in 1997 was an interpreter service for Indigenous languages trialled in the Top End of the Northern Territory. According to Senator Trish Crossin (who spoke on this matter in 1999), Denis Burke, the then Territory's chief minister, had rejected the need for an Aboriginal interpreter service, saying that it was a disgrace that Aboriginal people still needed them: 'to my mind (that) is akin to providing a wheelchair for someone who should be able to walk'. ${ }^{3}$

Only in 2008 did TAFE SA begin operating an interpreter training program on the APY Lands. Before that, two elderly people - Mona Tur and Bill Edwards - did much of the interpreting for Pitjantjatjara people in Adelaide, covering high stakes legal and medical interpreting. ${ }^{54}$

This lack of awareness of communicative language needs continued to cause serious problems for Indigenous people. It also caused problems for the federal government during the Northern Territory National

50 Amery and Williams, 'Reclaiming Through'; Committee for Geographical Names in Australasia, 'Guidelines for the Recording'; Reid, 'Creating Aboriginal Placenames'.

51 Merlan, 'Recent Rituals'.

52 Jacqueline Battin, 'Indigenous Languages in Australian Parliaments', AIATSIS (blog), Australian Institute of Aboriginal and Torres Strait Studies, 21 May 2018, accessed 2 June 2019, aiatsis.gov.au/ news-and-events/blog/Indigenous\%20Australian\%20Languages.

53 Commonwealth Parliamentary Debates, Senate, Matters of Public Interest, 8 December 1999, 11416.

54 House Standing Committee on Aboriginal and Torres Strait Islander Affairs, Our Land, Our Languages; Bill Edwards pers. comm. to Jane Simpson. See also Simpson, Amery and Gale, 'I Could Have Saved You', 100. 
Emergency Response (the 'Intervention') of 2007: how to convey the unpleasant information that Indigenous people's freedoms would be curtailed in the name of improving their general welfare. In 2008, the head of the federal government Intervention taskforce, Major General David Chalmers, said that a major and unforeseen challenge had been the difficulty of communicating with Aboriginal people..$^{55}$ The responsible policymakers simply had not understood that many Northern Territory Aboriginal people did not speak English well, and the taskforce had not made effective use of interpreters.

Finally, with respect to the communicative right to mother-tongue medium education, the promise and hopes of the 1970s and 1980s faded in the 1990s and 2000s. Right from the start, 'bilingual education' programs had suffered from public conflation of different language rights: the identity right to preserve Indigenous languages, the communicative right to learn the language of wider communication (SAE) and the communicative right of children to be taught in a language they understand. Opponents of mother-tongue medium education argued that its supporters simply had a romantic desire to preserve Indigenous languages at the expense of the children learning English. They did not realise that children could grow up bilingual with proper teaching of English and maintenance of their first languages.

Some Indigenous people also argued against mother-tongue medium instruction as they were convinced of the importance of learning SAE, and they blamed a mother-tongue medium instruction program for the poor English language skills of their children. The longstanding Pitjantjatjara program fell victim to this argument in 1990 when the Indigenous-controlled Pitjantjatjara/Yankunytjatjara Education Committee recommended an English-only approach, asserting that schools should focus on teaching children English and that families could maintain Pitjantjatjara at home. ${ }^{56}$ The results did not bear out their hopes, and older teachers began calling for a return to mother-tongue medium instruction. In 2018 the state government announced a return to mothertongue medium instruction. ${ }^{57}$

55 Smiles, 'Five Years'.

56 Anangu coordinators, 'Submission 116'.

57 Department of Education South Australia, Aboriginal Education Strategy. 
A major blow to bilingual education and, indirectly, to real self-determination was caused by changes to BIITE's and SAL's funding and educational frameworks ${ }^{58}$ that made it hard for remote area Indigenous people to gain teacher qualifications. While BIITE expanded its student numbers in the early 2000 s, reaching over 3,000 in $2003,{ }^{59}$ the numbers of Indigenous students from remote communities declined rapidly, due in part to the abolition of in-community training. In 2008 only two Aboriginal teachers graduated from BIITE. ${ }^{60}$ By 2017 BIITE had stopped operating a teacher training program. The Institute for Aboriginal Development had had to wind down its vocational training role and, in 2019 , it went into voluntary administration. Because these decisions have choked off the source of young trained Indigenous teachers and other professionals, the consequences are terrible for communities, with the loss of support for the plans, hopes and enthusiasm of this generation.

\section{Conclusion}

The language ecologies of Indigenous Australians are changing rapidly. Fewer people are speaking traditional Indigenous languages as their first language, while more are speaking new Indigenous languages as their first languages. ${ }^{61}$ At the same time, the diaspora of speakers of Indigenous languages in cities such as Darwin, Alice Springs and Adelaide is growing, as people seek better access to services. This means that the chances for communities to maintain their traditional Indigenous languages are rapidly diminishing.

Since the beginning of the self-determination policy, identity rights have been strengthened. Governments and communities are investing in Indigenous language revival, and in emblematic gestures such as naming places with Indigenous names and using Indigenous languages at public events. However, with respect to communication rights, the picture is patchier. ${ }^{62}$ Major polices, such as the Intervention, were implemented

\footnotetext{
58 Black and Breen, 'The School of Australian Linguistics'; Reaburn, Bat and Kilgariff, 'Looking for a New Common Ground'.

59 Gilbey and McCormack, 'Telling Histories'.

60 Devlin, Disbray and Devlin, History of Bilingual, 206.

61 Simpson and Wigglesworth, 'Language Diversity'.

62 See papers in Jane Simpson, Samantha Disbray and Carmel O'Shannessy, eds, 'Teaching and Learning Australian Aboriginal and Torres Strait Islander Languages', special issue Babel (Journal of the Australian Federation of Modern Language Teachers' Associations) 54, no. 1-2 (2019).
} 
without proper consideration of communication needs. Subsequently, interpreter services in Indigenous languages have expanded, and governments have made more effort to put information in Indigenous languages. But children still have only limited access to education in their mother-tongue along with proper explicit teaching of English. The move to monolingual English immersion education has been accompanied by the reduction of opportunities for remote Indigenous communities to obtain tertiary training (whether as teachers, interpreters or health workers) in their home communities. These two factors have greatly reduced the opportunities for people living in remote Indigenous communities to access information in order to make the best decisions for themselves and their families. At the same time, the aims of giving children good access to English, and to the content of education, have not so far been achieved.

\section{In 1981 Kenneth Liberman wrote:}

The problem, as the Aboriginal people view it, is that too many of the important everyday decisions in their remote communities are being made by European officials who work for one of these three government bureaucracies. At each Aboriginal central settlement, European officials live in a mini-suburb of portable houses, surrounded by high fences. The majority of Europeans do not speak the Aboriginal language and know little about Aboriginal life. In most cases, they remain for only one or two years, and yet they are actively involved in setting administrative policies for the settlements. ${ }^{63}$

The policy of self-determination was supposed to change that perception. In 2019 it seems that not much has changed for Indigenous people in remote communities.

\section{References}

Amagula, Jacqueline and Helen C. D. McCarthy. 'Red Ochre Women: Sisters in the Struggle for Educational Reform'. In Finding Common Ground: Narratives, Provocations and Reflections from the 40 Year Celebration of Batchelor Institute, edited by Henk Huijser, Robyn Ober, Sandy O'Sullivan, Eva McRae-Williams and Ruth Elvin, 62-68. Batchelor, NT: Batchelor Press, 2015.

63 Liberman, 'Aboriginal Education', 140. 
Amery, Rob and Georgina Yambo Williams. 'Reclaiming through Renaming: The Reinstatement of Kaurna Toponyms in Adelaide and the Adelaide Plains'. In The Land Is a Map: Placenames of Indigenous Origin in Australia, edited by Luise Hercus, Flavia Hodges and Jane Simpson, 255-76. Canberra: Pacific Linguistics and Pandanus Press, 2002. doi.org/10.22459/1m.03.2009.18.

Anangu coordinators. 'Submission 116'. In Our Land, Our Languages: Language Learning in Indigenous Communities, edited by the House Standing Committee on Aboriginal and Torres Strait Islander Affairs. Canberra: Commonwealth of Australia, 2012.

Black, Paul and Gavan Breen. 'The School of Australian Linguistics'. In Forty Years On, edited by Jane Simpson, David Nash, Mary Laughren, Peter Austin and Barry Alpher, 161-78. Canberra: Pacific Linguistics, 2001.

Brennan, Gloria. The Need for Interpreting and Translation Services for Australian Aboriginals, with Special Reference to the Northern Territory: A Research Report. Canberra: Research Section, Department of Aboriginal Affairs, 1979.

Committee for Geographical Names in Australasia. 'Guidelines for the Recording and Use of Aboriginal and Torres Strait Islander Place Names'. In The Land Is a Map: Placenames of Indigenous Origin in Australia, edited by Luise Hercus, Flavia Hodges and Jane Simpson, 276-81. Canberra: Pacific Linguistics and Pandanus Press, 2002. doi.org/10.26530/oapen_459353.

Commonwealth Parliamentary Debates. Senate. 'Matters of Public Interest: Aboriginals: Interpreter Service', 8 December 1999, 11414-17.

Department of Education South Australia. Aboriginal Education Strategy 20192029. Adelaide: Government of South Australia, 2018.

Devlin, Brian. 'A Glimmer of Possibility'. In History of Bilingual Education in the Northern Territory: People, Programs and Policies, edited by Brian Devlin, Samantha Disbray and Nancy Regine Friedman Devlin, 11-24. Singapore: Springer, 2017. doi.org/10.1007/978-981-10-2078-0_2.

Devlin, Brian, Samantha Disbray and Nancy Regine Friedman Devlin, eds. History of Bilingual Education in the Northern Territory: People, Programs and Policies. Singapore: Springer, 2017. doi.org/10.1007/978-981-10-2078-0_5.

Gale, Kathryn. 'Lessons Learned from Bilingual Education'. In History of Bilingual Education in the Northern Territory: People, Programs and Policies, edited by Brian Devlin, Samantha Disbray and Nancy Regine Friedman Devlin, 49-60. Singapore: Springer, 2017. doi.org/10.1007/978-981-10-2078-0_1. 
Gale, Mary-Anne. 'Boom and Then Bust: Lessons Learnt from My Time Teaching in Three Bilingual Schools in the Northern Territory'. In History of Bilingual Education in the Northern Territory: People, Programs and Policies, edited by Brian Devlin, Samantha Disbray and Nancy Regine Friedman Devlin, 73-84. Singapore: Springer, 2017. doi.org/10.1007/978-981-10-2078-0_7.

Gilbey, Kathryn and Rob McCormack. 'Telling Histories: Performing History, Becoming History'. In Testimony, Witness, Authority: The Politics and Poetics of Experience, edited by Tom Clark, Tara Mokhtari and Sasha Henriss-Anderssen, 130-43. Newcastle upon Tyne, UK: Cambridge Scholars Publisher, 2014.

Graham, Beth. 'Reflecting on Team Teaching'. In History of Bilingual Education in the Northern Territory: People, Programs and Policies, edited by Brian Devlin, Samantha Disbray and Nancy Regine Friedman Devlin, 27-33. Singapore: Springer, 2017. doi.org/10.1007/978-981-10-2078-0_3.

Holcombe, Sarah E. Remote Freedoms: Politics, Personhood, and Human Rights in Aboriginal Central Australia. Stanford, CA: Stanford University Press, 2018.

Hoogenraad, Robert. 'Critical Reflections on the History of Bilingual Education in Central Australia'. In Forty Years On, edited by Jane Simpson, David Nash, Mary Laughren, Peter Austin and Barry Alpher, 123-50. Canberra: Pacific Linguistics, 2001.

House Standing Committee on Aboriginal and Torres Strait Islander Affairs. 2012. Our Land, Our Languages: Language Learning in Indigenous Communities. Canberra: Commonwealth of Australia.

Hudson, Joyce and Patrick McConvell. Keeping Language Strong: Report of the Pilot Study for the Kimberley Language Resource Centre. Halls Creek, WA: Kimberley Language Resource Centre, 1984.

Huijser, Henk, Robyn Ober, Sandy O'Sullivan, Eva McRae-Williams and Ruth Elvin, eds. Finding Common Ground: Narratives, Provocations and Reflections from the 40 Year Celebration of Batchelor Institute. Batchelor, NT: Batchelor Press, 2015.

Keeffe, Kevin. From the Centre to the City: Aboriginal Education, Culture and Power. Canberra: Aboriginal Studies Press, 1992.

Liberman, Kenneth. 'Aboriginal Education: The School at Strelley, Western Australia'. Harvard Educational Review 51 (1981): 139-44. doi.org/10.17763/ haer.51.1.v93x127q438k160p.

Lo Bianco, Joseph. National Policy on Languages. Canberra: Australian Government Publishing Service, 1987. 
Macdonald, Lance, Sheila Dixon, Sarah Holcombe and Ken Hansen. Universal Declaration of Human Rights: Pintupi-Luritja. UN Human Rights (Office of the High Commissioner for Human Rights), 2015.

Marika, Raymattja. 'The 1998 Wentworth Lecture'. Australian Aboriginal Studies 99, no. 1 (1999): 3-9.

Marika-Mununggiritj, Raymattja, Banbapuy Maymuru, Multhara Mununggurr, Badang'thun Munyarryun, Gandalal Ngurruwutthun and Yalmay Yunupingu. 'The History of the Yirrkala Community School: Yolngu2 Thinking about Education in the Laynha and Yirrkala Area'. Ngoonjook, no. 3 (September 1990): 32-52.

McMahon, William. Australian Aborigines: Commonwealth Policy and Achievements. Statement by the Prime Minister, The Rt Hon. William McMahon, C.H., M.P. W.G. Murray, Government Printer, 1972.

Meehan, Dorothy. 'Starting Out at Bamyili: Factors Specific to the Development of the Kriol Program'. In History of Bilingual Education in the Northern Territory: People, Programs and Policies, edited by Brian Devlin, Samantha Disbray and Nancy Regine Friedman Devlin, 61-71. Singapore: Springer, 2017. doi.org/10.1007/978-981-10-2078-0_6.

Merlan, Francesca. 'Recent Rituals of Indigenous Recognition in Australia: Welcome to Country'. American Anthropologist 116 (2014): 296-309. doi.org/ 10.1111/aman.12089.

Nicholls, Christine. 'Death by a Thousand Cuts: Indigenous Language Bilingual Education Programmes in the Northern Territory of Australia, 1972-1998'. International Journal of Bilingual Education and Bilingualism 8 (2005): 160-77. doi.org/10.1080/13670050508668604.

O'Grady, Geoff and Ken Hale. 'Recommendations concerning Bilingual Education in the Northern Territory July 1974'. Parliamentary Paper No. 329. Canberra: The Parliament of the Commonwealth of Australia, 1975.

Pybus, Carol Ann. “'We Grew Up This Place”: Ernabella Mission 1937-1974'. $\mathrm{PhD}$ thesis, University of Tasmania, 2012.

Rademaker, Laura. Found in Translation: Many Meanings on a North Australian Mission. Honolulu: University of Hawai'i Press, 2018. 
Reaburn, Sue, Melodie Bat and Claire Kilgariff. 'Looking for a New Common Ground: A Reflection on Batchelor Institute's Teacher Education Training Programs for Remote Aboriginal Education Professionals in the Northern Territory'. In Finding Common Ground: Narratives, Provocations and Reflections from the 40 Year Celebration of Batchelor Institute, edited by Henk Huijser, Robyn Ober, Sandy O'Sullivan, Eva McRae-Williams and Ruth Elvin, 31-42. Batchelor, NT: Batchelor Press, 2015.

Reid, Nicholas. 'Creating Aboriginal Placenames: Applied Philology in Armidale City'. In The Land Is a Map: Placenames of Indigenous Origin in Australia, edited by Luise Hercus, Flavia Hodges and Jane Simpson, 241-54. Canberra: Pacific Linguistics and Pandanus Press, 2002. doi.org/10.22459/lm.03.2009.17.

Ross, Tess and Wendy Baarda. 'Starting Out at Yuendumu School - Teaching in Our Own Language'. In History of Bilingual Education in the Northern Territory: People, Programs and Policies, edited by Brian Devlin, Samantha Disbray and Nancy Regine Friedman Devlin, 247-57. Singapore: Springer, 2017. doi.org/10.1007/978-981-10-2078-0_20.

Sandefur, John R. Kriol of North Australia: A Language Coming of Age. Work papers of SIL-AAB. Series A, vol. 10. Darwin: Summer Institute of Linguistics, Australian Aborigines Branch, 1986.

Sandefur, John R. and David N. Jentian. 'A Tentative Description of the Phonemes of the Ngalkbun Language (including a Small Word List)'. In Five Papers in Australian Phonologies, edited by Joyce Hudson, 57-96. Darwin: Summer Institute of Linguistics, 1977.

Simpson, Jane, Robert Amery and Mary-Anne Gale. 'I Could Have Saved You Linguists a Lot of Time and Trouble: 178 Years of Research and Documentation of South Australia's Indigenous Languages, 1826-2004'. In Encountering Aboriginal Languages: Studies in the History of Australian Linguistics, edited by William B. McGregor, 85-144. Canberra: Pacific Linguistics, 2008.

Simpson, Jane and Gillian Wigglesworth. 'Language Diversity in Indigenous Australia in the 21st Century'. Current Issues in Language Planning, 19 (2018): 67-80. doi.org/10.1080/14664208.2018.1503389.

Smiles, Sarah. 'Five Years “Too Short” for NT Intervention'. The Age (Melbourne), 2008.

Sommerlad, Elisabeth. Kormilda: The Way to Tomorrow? A Study in Aboriginal Education. Canberra: Australian National University Press, 1976.

Trudinger, David. 'Converting Salvation: Protestant Missionaries in Central Australia, 1930s-40s'. PhD thesis, The Australian National University, 2011. 
United Nations General Assembly. International Covenant on Economic, Social and Cultural Rights, 16 December 1966. United Nations, Treaty Series, vol. 993, pp. 3-12. doi.org/10.18356/f95a34ca-en-fr.

United Nations General Assembly. International Covenant on Civil and Political Rights, 16 December 1966. United Nations, Treaty Series, vol. 999, pp. 17186. doi.org/10.18356/b703d8a8-en-fr.

Underwood, Bruce. Response to: Achieving Equitable and Appropriate OutcomesIndigenous Australians in Higher Education [Backing Australia's Future, DEST]. AnTEP, University of South Australia, 2002.

Vaarzon-Morel, Petronella and Jim Wafer. "Bilingual Time" at Willowra: The Beginnings of a Community-Initiated Program, 1976-1977’. In History of Bilingual Education in the Northern Territory: People, Programs and Policies, edited by Brian Devlin, Samantha Disbray and Nancy Regine Friedman Devlin, 35-48. Singapore: Springer, 2017. doi.org/10.1007/978-981-10-2078-0_4.

Watts, Betty H. and James D. Gallacher. Report on an Investigation into the Curriculum and Teaching Methods Used in Aboriginal Schools in the Northern Territory to C. E. Barnes, Minister of State for Territories. Darwin: Australian Department of Territories, 1964.

Watts, Betty H., William McGrath and James Linsley Tandy. Recommendations for the Implementation and Development of a Program of Bilingual Education in Schools in Aboriginal Communities in the Northern Territory. Canberra: Department of Education, 1973.

White, Leon. 'Finding the Common Ground with Indigenous and Western Knowledge Systems and Seeking the Common Good for All Present and Future Australians - Where Is the Common Ground if We Are Going to Find It?' In Finding Common Ground: Narratives, Provocations and Reflections from the 40 Year Celebration of Batchelor Institute, edited by Henk Huijser, Robyn Ober, Sandy O'Sullivan, Eva McRae-Williams and Ruth Elvin. Batchelor, NT: Batchelor Press, 2015.

Wilkins, David. 'Linguistic Research under Aboriginal Control: A Personal Account of Fieldwork in Central Australia'. Australian Journal of Linguistics 12 (1992): 171-200. doi.org/10.1080/07268609208599475.

Zoellner, Don. Vocational Education and Training: The Northern Territory's History of Public Philanthropy. Canberra: ANU Press, 2017. 
This text is taken from Indigenous Self-Determination in Australia: Histories and Historiography, edited by Laura Rademaker and Tim Rowse, published 2020 by ANU Press, The Australian National University, Canberra, Australia.

doi.org/10.22459/ISA.2020.13 